International Journal of Trend in Scientific Research and Development (IJTSRD) ISSN: 2456-6470

\section{CLASSES OF DAMAGE:}

\begin{tabular}{|l|l|l|}
\hline $\begin{array}{l}\text { Class of } \\
\text { Damage }\end{array}$ & $\begin{array}{l}\text { Repair } \\
\text { classification }\end{array}$ & $\begin{array}{l}\text { Repair Requirements } \\
\text { bonding }\end{array}$ \\
\hline Class 1 & Superficial & $\begin{array}{l}\text { Non-structural or minor structural repairs like restoring cover to } \\
\text { reinforcement using cement polymer slurry as bonding layer and } \\
\text { nominal light fabric reinforcement or using epoxy mortar over the } \\
\text { primary coat of epoxy primer. }\end{array}$ \\
\hline Class 3 & Principal Repair & $\begin{array}{l}\text { Where concrete strength is significantly reduced, } \\
\text { strengthening to be carried out with shotcreting in case of slabs and } \\
\text { beams and jacking in case of columns. For less damaged columns } \\
\text { shotcreting is also proposed }\end{array}$ \\
\hline Class 4 & Major repair & \begin{tabular}{l} 
Repair method is demolition \\
\hline
\end{tabular}
\end{tabular}

\section{LITERATURE REVIEW}

Fire remains one in every of the intense potential risks to most buildings and structures. The intensive use of concrete as a structural material has semiconductor diode to the necessity to completely perceive the impact of fireplace on concrete. Typically concrete is assumed to own smart fireplace resistance. The behavior of ferroconcrete columns below extreme temperature is especially tormented by the strength of the concrete, the changes of fabric property and explosive spalling.

The hardened concrete is dense, homogenized and has a minimum of a similar engineering properties and sturdiness as ancient vibrated concrete. However, high temperatures have an effect on the strength of the concrete by explosive spalling then have an effect on the integrity of the concrete structure.

\section{EXPERIMENTAL WORK}

INTRODUCTION: The specimens for testing were TMT bar of $16 \mathrm{~mm}$ diameter. 50 bars were move $40 \mathrm{~cm}$ size. 5 Specimens were tested for the mechanical properties victimisation UTM before heating at traditional temp and also the properties were tabulated. 12 specimens every were heated within the electrical chamber at $150^{\circ}, 350^{\circ}, 650^{\circ}$ associate degreed $950^{\circ} \mathrm{C}$ for an hour with none disturbance once heating, out of 12 specimens for every temperature 6 samples were quenched in water for speedy cooling and also the different 6 were unbroken aside for traditional cooling at atmospherical temperature. These specimens later were tested for mechanical properties with UTM and microstructure study victimisation SEM.

\section{EQUIPEMENT:}
i.) Universal Testing Machine
ii.) Scanning Electron Microscope
iii.) Electrical Furnace

RESULTS FROM AUTOMATIC UTM:

Table1: Properties for rapid cooling conditions

\begin{tabular}{|c|c|c|c|c|c|c|c|}
\hline $\begin{array}{l}\text { S. } \\
\text { NO }\end{array}$ & $\begin{array}{c}\text { Temp in } \\
\circ \mathrm{C}\end{array}$ & $\begin{array}{c}\text { Ultimate } \\
\text { load }(\mathrm{kN})\end{array}$ & $\begin{array}{c}\text { Ultimate } \\
\text { stress } \\
\left(\mathrm{kN} / \mathrm{mm}^{2}\right)\end{array}$ & $\begin{array}{c}\text { Yield } \\
\text { stress } \\
\left(\mathrm{kN} / \mathrm{mm}^{2}\right)\end{array}$ & $\begin{array}{c}\text { Max. } \\
\text { Extension } \\
(\mathrm{mm})\end{array}$ & $\begin{array}{c}\text { Elongation } \\
(\%)\end{array}$ & $\begin{array}{c}.2 \% \\
\text { proof } \\
\text { stress }\end{array}$ \\
\hline 1 & 2 & 67.1 & 0.583 & 0.446 & 1.64 & 27.6 & 0.454 \\
\hline 2 & 1 & 66.4 & 0.589 & 0.489 & 1.76 & 35 & 0.464 \\
\hline 3 & 3 & 66.8 & 0.611 & 0.459 & 1.521 & 27. & 0.456 \\
\hline 4 & 6 & 69.7 & 0.632 & 0.467 & 0.956 & 27.5 & 0.472 \\
\hline 5 & 9 & 81.2 & 0.711 & 0.476 & 0.224 & 13.8 & 0.554 \\
\hline
\end{tabular}


International Journal of Trend in Scientific Research and Development (IJTSRD) ISSN: 2456-6470

Table2: Properties for ordinary cooling conditions

\begin{tabular}{|l|l|l|l|l|l|l|l|}
\hline $\begin{array}{l}\text { S.N } \\
\mathbf{O}\end{array}$ & $\begin{array}{l}\text { Temp in } \\
{ }^{\circ} \mathrm{C}\end{array}$ & $\begin{array}{l}\text { Ultimate } \\
\text { load }(\mathrm{kN})\end{array}$ & $\begin{array}{l}\text { Ultimate } \\
\text { stress } \\
(\mathrm{kN} / \mathrm{mm} 2)\end{array}$ & $\begin{array}{l}\text { Yield } \\
\text { stress } \\
\left(\mathrm{kN} / \mathrm{mm}^{2}\right)\end{array}$ & $\begin{array}{l}\text { Max. } \\
\text { Extension } \\
(\mathrm{mm})\end{array}$ & $\begin{array}{l}\text { Elongatio } \\
\mathbf{n} \\
(\%)\end{array}$ & $\begin{array}{l}.2 \% \text { proof } \\
\text { stress } \\
(\mathrm{kN} / \mathrm{mm} 2)\end{array}$ \\
\hline 1 & 27 & 67.1 & 0.583 & 0.446 & 1.64 & 27.6 & 0.454 \\
\hline 2 & 150 & 66.7 & 0.578 & 0.462 & 1.154 & 34.2 & 0.456 \\
\hline 3 & 350 & 64.9 & 0.580 & 0.443 & 1.131 & 29.5 & 0.436 \\
\hline 4 & 650 & 66.5 & 0.583 & 0.491 & 0.865 & 28.41 & 0.453 \\
\hline 5 & 950 & 68.7 & 0.596 & 0.472 & 0.720 & 28.5 & 0.448 \\
\hline
\end{tabular}

For RAPID cooling conditions:

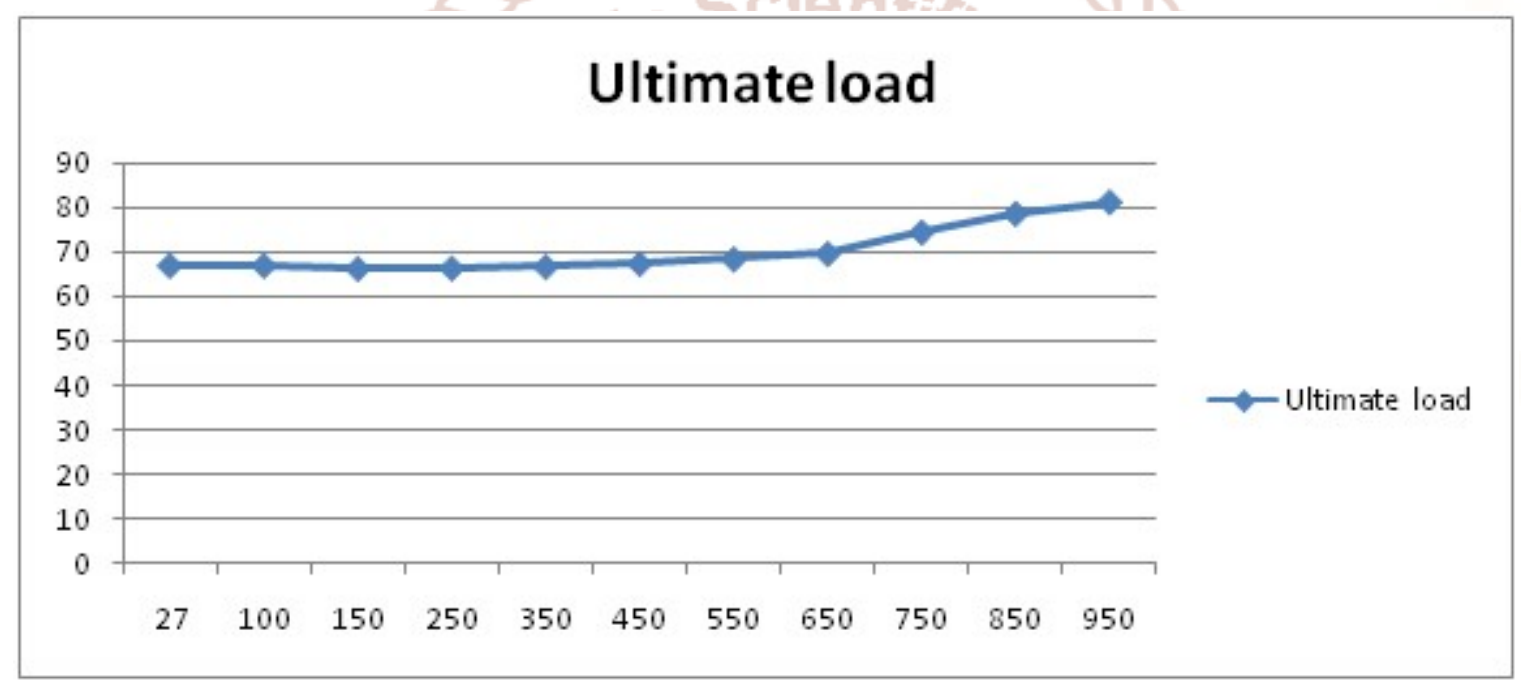

Fig : Temperature vs ultimate load

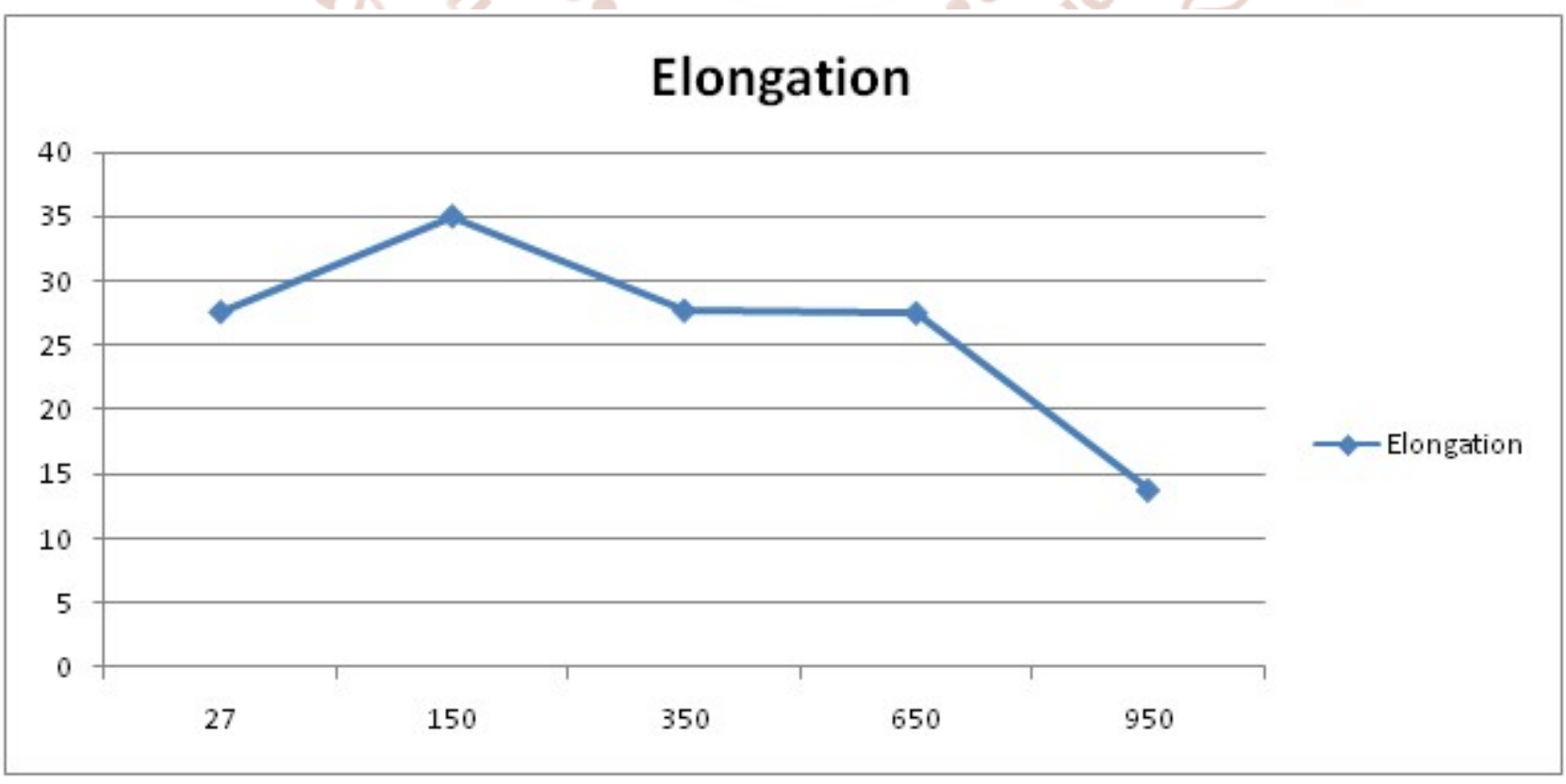

Fig : Temperature vs \% Elongation 
International Journal of Trend in Scientific Research and Development (IJTSRD) ISSN: 2456-6470

From the above Fig. it can be observed that ultimate stress initially decreases and then gradually increases, with increase in temperature, this happens due to the microstructure of the bar. For high temperatures the grain size decreases.

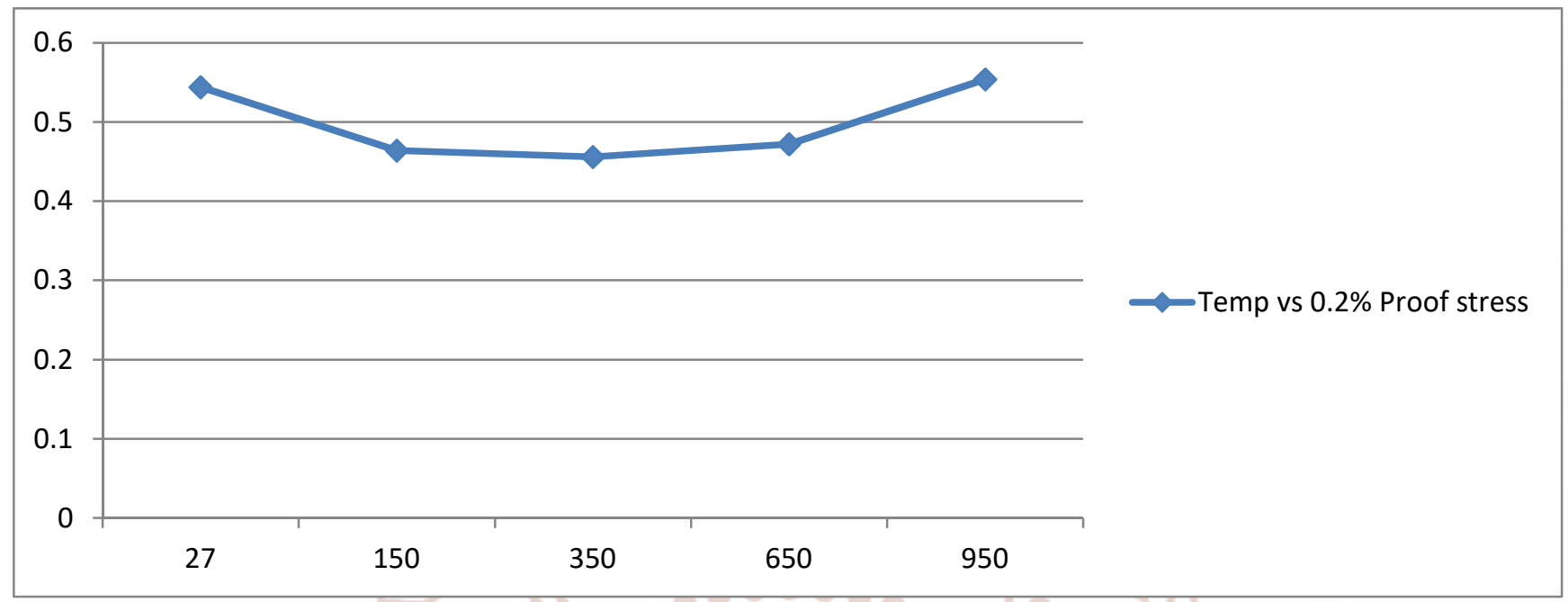

Fig: $0.2 \%$ Proff stress vs temperature

From the above Fig. it can be observed that the proof stress initially constant then decreases and then gradually increases, while we increases the temperature.

For ORDINARY cooling conditions:

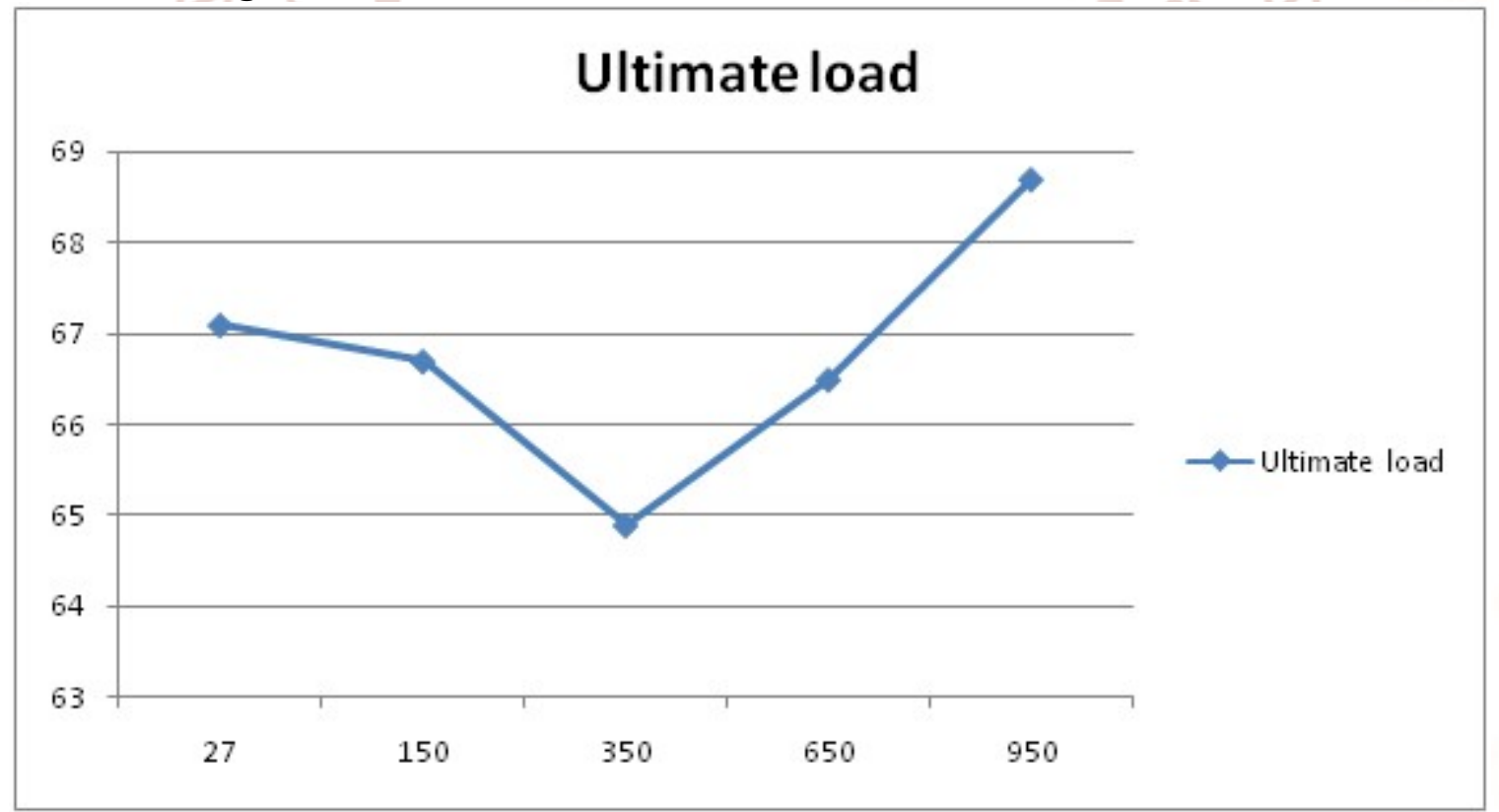

Fig : Temperature vs ultimate load

From the above Fig, the ultimate load carrying capacity of the specimen was reduced in the specimen before heating. 


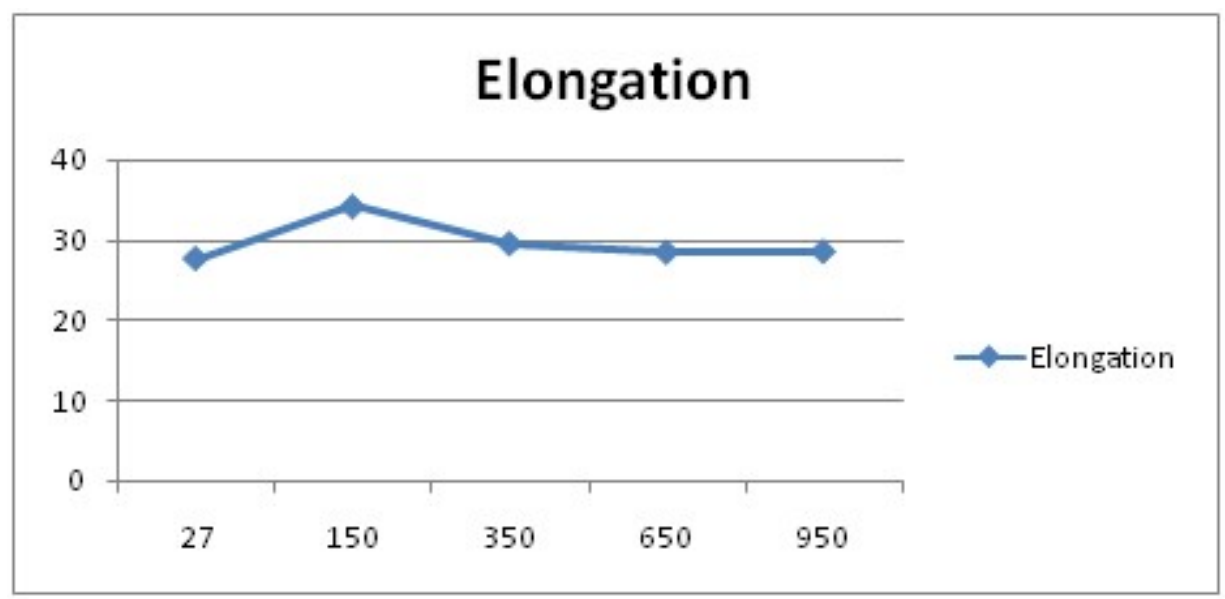

Fig: Temperature vs Elongation

From the above Fig. it can be observed that the \% Elongation initially increases upto a point and then gradually decreases. For high temperatures the grain size decreases.

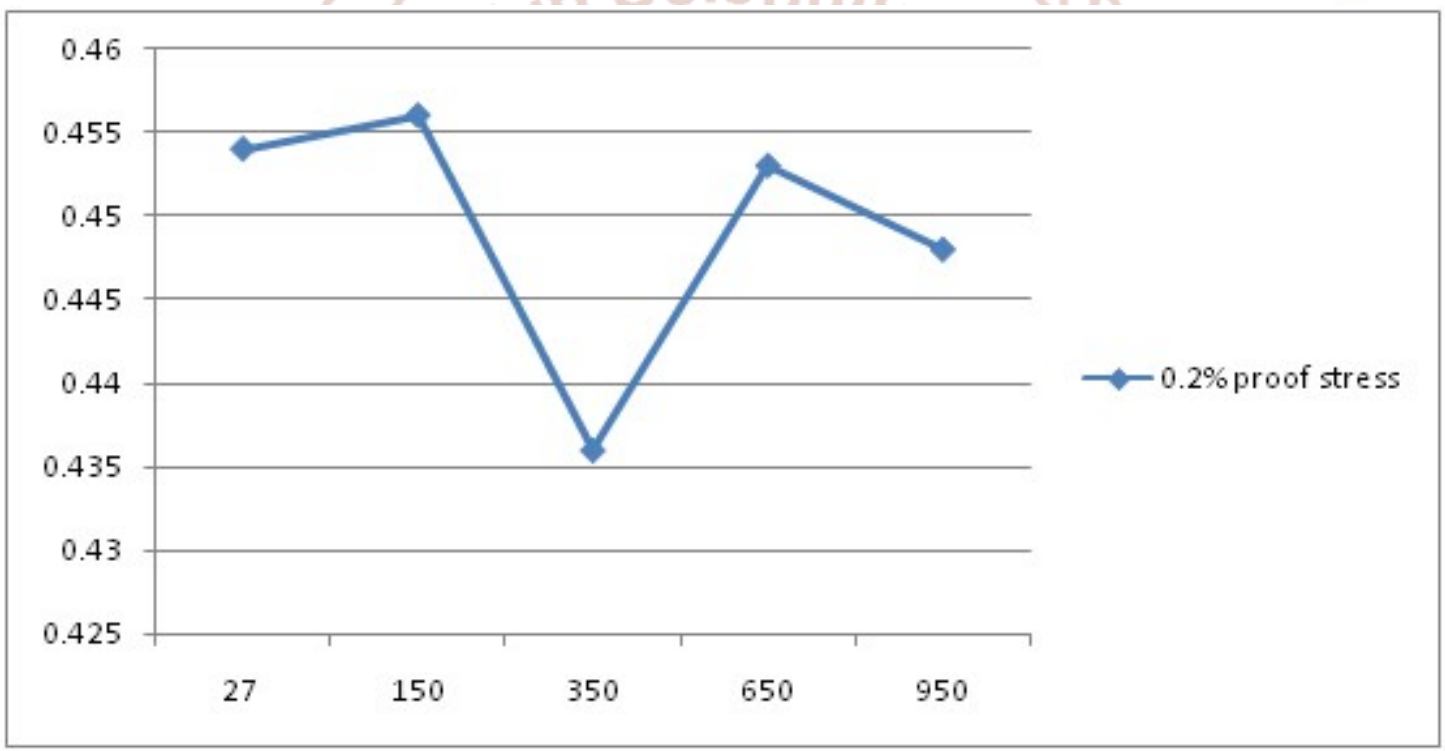

Fig: Temperature vs .2\% Proof stress

In above fig it shows the variation between temperature and proof stress in which the proof stress first decreases then suddenly increases up to certain limit after which again start decreasing.

\section{CONCLUSION}

i.) The impact of fireside on the reinforcement bars heated at numerous temp of $150^{\circ} \mathrm{C} 350^{\circ} \mathrm{C}$, $650^{\circ} \mathrm{C}, 950^{\circ} \mathrm{C}$, cooled quickly by termination in water and usually cooled within the atmospherical temp were studied and it's ascertained that the plasticity of quickly cooled bars once heating to extreme temperature to $950^{\circ}$ C.

ii.) Finding out the characteristic changes in the mechanical properties of the bars by enduringness testing victimisation $\mathrm{U} T \mathrm{M}$ shows that the rise in final load and reduce in proportion elongation of

the specimen that mean that there's important decrease in plasticity of the specimen..

\section{REFERENCES}

1. Alia F, Nadjai A, Silcock G, Abu-Tair A, Outcomes of a major research on fire resistance of concrete columns, Fire Safety Journal 39 (2004) $433-445$.

2. Arioz O, Effects of elevated temperatures on properties of concrete, Fire Safety Journal 42 (2007) 516-522. 
3. Balázs L.G, Lublóy É, Mezei S, Potentials in concrete mix design to improve fire resistance, Concrete Structures, 2010.

4. Bilow D.N., Kamara M.E., Fire and Concrete Structures, Structures 2008.

5. Chen Y.H, ChangY.F, Yao G.C, Sheu M.S , Experimental research on post-fire behaviour of reinforced concrete columns, Fire Safety Journal 44 (2009) 741-748.

6. Chowdhurya E.U, Bisbya L.A, Greena M.F, Kodur V.K.R, Investigation of insulated FRPwrapped reinforced concrete columns in fire, Fire Safety Journal 42 (2007) 452-460.

7. Chi-Sun poon, Salman Azhar, Mike Anson, YukLung Wong. Strength and sturdiness recovery of fire-damaged concrete once post-fire-curing. Honkong engineering school university-2000.

8. Cooke, R.A. and Rodger, H., Principles of fireplace Investigation. 1985. Principles of fireside Investigation. Kent: Institute of fireside Engineers. 